\title{
Sexual Behaviour Among Senior Secondary School Students in Nnewi North and NnewiSouth Local Government Areas of Anambra State, South-Eastern Nigeria
}

\author{
Azuike Emmanuel Chukwunonye ${ }^{1, ~ *, ~ I l o g h a l u ~ I f e o m a ~ C h i s o m ~}{ }^{1}$, Nwabueze Simeon Achunam ${ }^{1}$, \\ Emelumadu Obiageli Fidelia ${ }^{1}$, Balogun John Seyifumi ${ }^{1}$, Azuike Ebele Dabeluchukwu ${ }^{2}$, \\ Obi Kamtoochukwu Mmaduneme ${ }^{1}$, Enwonwu Kenechukwu Grace ${ }^{1}$, Ebulue Charles Chukwudalu ${ }^{1}$, \\ Obi Darlington Chukwudinma ${ }^{1}$, Chikezie Nkiru Ifeoma ${ }^{1}$
}

${ }^{1}$ Department of Community Medicine, Nnamdi Azikiwe University Teaching Hospital, Nnewi, Nigeria
${ }^{2}$ Department of Nursing Sciences, Faculty of Health Sciences, Nnamdi Azikiwe University, Awka, Nigeria

Email address:

emmanazuike@yahoo.com (Azuike E. C.)

\section{To cite this article:}

Azuike Emmanuel Chukwunonye, Iloghalu Ifeoma Chisom, Nwabueze Simeon Achunam, Emelumadu Obiageli Fidelia, Balogun John Seyifumi, Azuike Ebele Dabeluchukwu, Obi Kamtoochukwu Mmaduneme, Enwonwu Kenechukwu Grace, Ebulue Charles Chukwudalu, Obi Darlington Chukwudinma, Chikezie Nkiru Ifeoma. Sexual Behaviour Among Senior Secondary School Students in Nnewi North and Nnewi South Local Government Areas of Anambra State, South-Eastern Nigeria. European Journal of Preventive Medicine.

Vol. 3, No. 2, 2015, pp. 26-33. doi: 10.11648/j.ejpm.20150302.13

\begin{abstract}
INTRODUCTION: Many adolescents engage in risky sexual activity without protection as shown by recent WHO report and this practice commonly resulted in sexually transmitted infections (STIs) including human immunodeficiency virus (HIV), unwanted pregnancy and unsafe abortion. OBJECTIVE: This study is intended to describe the sexual behaviour of students in senior secondary schools in Nnewi North and South LGAs of Anambra State, South-eastern Nigeria and to describe their attitude toward contraceptive use for the prevention of pregnancy and STIs. METHOD: A descriptive cross-sectional study which employed multi-stage and proportionate sampling techniques was conducted. RESULT: A total of 394 students, age range of $12-24$ years with mean of $17 \pm 1.6 y e a r s$ were studied. 95 (24.1\%) admitted to previous sexual exposure with mean age at sexual debut of $12 \pm 3.6$ years. More than half of them had multiple sex partners and learnt about sex from the media. $74.7 \%$ of the respondents did not use condom during their first sexual exposure and $83.3 \%$ of those who had been pregnant or got someone pregnant terminated the pregnancy. CONCLUSION: This study shows a need for better government and societal commitment to adolescent reproductive health issues and incorporation of school-based interventions relating to sexuality education into school curriculum.
\end{abstract}

Keywords: Sexual Behaviour, Secondary School Students

\section{Introduction}

Young people are at the beginning of their sexual and reproductive lives. Physiologically, the changes in reproductive organs that occur in the life of adolescents often serve as a motivating force in their quest to experiment with sex. Some naturally explore and take risks in many aspects of their lives, including sexual relationships. Those who have sex may change partners frequently and have more than one partner in the same time period or engage in unprotected sex.
These risky sexual activities make this group disproportionately affected by reproductive morbidities such as Sexually Transmitted Infections (STI) including Human Immuno-deficiency Virus (HIV) infection and Acquired Immune Deficiency Syndrome (AIDS), unwanted pregnancies and their complications ${ }^{[1-5]}$.

Human sexual behaviour refers to any activity (solitary, between two persons, or in a group), that induces sexual 
arousal. It may be the inherited sexual response patterns or other types of influence exerted on the individual by society in the expression of his sexuality ${ }^{[6]}$.Youth sexual behaviour is highly relevant to different public health problems ${ }^{[7,8]}$. For example, youth unprotected sexual intercourse contributes to unwanted pregnancies, abortions, pregnancy-related complications, and sexually transmitted infections (STIs) including HIV/AIDS ${ }^{[9]}$.

Adolescence represents a transition from childhood to adulthood with features including secondary sexual growth, changes in hormonal milieu, emotional, cognitive and psychological development ${ }^{[10,11,12]}$. They constitute about 20 percent of the world's population with about 85 percent of them in developing countries ${ }^{[13]}$. The sub-Saharan African countries, of which Nigeria is, have larger proportion of adolescents than any region in the world ${ }^{[14]}$.

Recent World Health Organization reports showed that many adolescents engage in risky sexual activity without protection and most had their sexual debut through a subtle coercion by their partner ${ }^{[15,16]}$. This practice commonly resulted in sexually transmitted infections (STIs), human immunodeficiency virus, unwanted pregnancy and unsafe abortion $^{[10,17,18]}$.

Studies within Africa including Nigeria have demonstrated increasing rate of premarital sex and decline in age of sexual debut among adolescents contrary to our moral and cultural values ${ }^{[14,19,20]}$. High poverty level, adoption ofwestern norm ofsexual liberty, gradual erosion of traditional norms/values, lack ofparental control, mass media, urbanization and tourism are some of the reasons that has been advanced for the above problems ${ }^{[20,21,22]}$.

The Joint United Nations Programme on AIDS (UNAIDS) reported that the rate of newly acquired HIV infections are the highest in the 15-25 years age- group and that this group accounts for about $60.0 \%$ of the global total of HIV infected persons ${ }^{[23]}$. Similarly, the highest sero-positive prevalence rate of HIV in Nigeria is in this age-group ${ }^{[24]}$.

On a global scale, according to the data from the Youth Risk Behaviour Survey $2011^{[25,26]}$, it was gathered that $47 \%$ of all high school students reported having had sexual intercourse, and this was significantly higher among boys (49\%) compared to girls $(46 \%)$. The proportion who have ever had sex also differed significantly by race/ethnicityrates were highest among non-Hispanic black students $(60 \%)$, followed by Hispanic and non-Hispanic white students $(49 \%$ and $44 \%$ respectively).Not surprisingly, this proportion also differed significantly by grade level, ranging from $33 \%$ of students in 9 th grade to $63 \%$ of students in 12th grade ${ }^{[25,26]}$.In the 2011 survey also, 6\% of high school students reported that they first had sex before age $13.15 \%$ of high school students reported having already had four or more sexual partners - rates were significantly higher among boys $(18 \%)$ compared to girls $(13 \%), 60 \%$ of sexually active students reported using a condom the last time they had sex, and $18 \%$ of sexually active students reported using birth control pills the last time they had sex ${ }^{[25,26]}$.

In Nigeria, the youth account for $32.0 \%$ of Nigerian's 140 million people and nearly half (48.6\%) of adolescents aged $15-19$ are sexually active ${ }^{[27]}$. Researches have confirmed that risky sexual behavior is associated with young people. These risky behaviors include: early debut in sexual activities, sex with many partners, low and inconsistent use of condoms, use of drugs and alcohol, anal sexual intercourse and mouth to genital contact ${ }^{[28-32]}$. About 1 in 5 of sexually active females and 1 in 12 of sexually active males had already engaged in sexual intercourse by the age of 15 . Findings from National AIDS and Reproductive Health Survey show that the median age of sexual debut among youths is 17 years in females and 21 years in males. A common feature of young people in Nigeria is their potential vulnerability to Sexually Transmitted Infections (STI) including HIV ${ }^{[27]}$. About 610,000 induced abortions are carried out in Nigeria annually ${ }^{[33]}$.In Delta State, a UNFPA sponsored baseline survey which included 1013 adolescents showed that $34.4 \%$ of adolescents aged between $15-19$ years have had sex ${ }^{[34]}$

Although adolescent reproductive health researchers have contributed to the understanding of sexual behaviour of young persons in Nigeria, the utility of the data are undermined by the fact that these studies were not widespread across the six geopolitical zones. Among the zones that have been poorly studied is the south-eastern Nigeria. There is paucity of published data on the sexual behaviour among secondary school students of the southeastern zone of Nigeria, especially in Nnewi North and South Local Government Areas (LGAs) of Anambra state. This study is intended to describe the sexual behaviour of students in senior secondary schools in Nnewi North and South LGAs of Anambra State, South-eastern Nigeria and to describe their attitude toward contraceptive use for the prevention of pregnancy and STIs.

\section{Materials and Methods}

The study was a descriptive cross-sectional study, conducted among senior secondary school students (grade 10-12 high school) in Nnewi North and South LGAs of Anambra State, Ngeria. Nnewi North LGA comprises four major villages, Otolo, Umudim, Uruagu and Nnewichi and is the less remote of the two LGAs while Nnewi South LGA comprises Ukpor, Ekwulumili, Amichi, Azigbo, Unubi, Ezinifite, Osumenyi, Utuh, Akwaihedi, Ogbodi and Ebenator.

There are 45 and 38 secondary schools in Nnewi North and Nnewi South LGA respectively ${ }^{[35]}$.The estimated number of senior secondary school students in the study area was obtained from the Post Primary School Service Commission and from the State Ministry of Education as 15,885 students in Nnewi North and 6,004 students in Nnewi South LGA.

The minimum sample size for the study was found to be 380 from the formula

$$
n=\frac{z^{2} p q}{d^{2}}
$$

Where, 
$n=$ desired sample size when population is greater than 10000 .

$d=$ Level of significance at $5 \%(0.05)$;

$z=$ confidence limits of the survey result, which equals 1.96 at $95 \%$ confidence level;

$p=$ proportion of persons in the target population with factors under study ( in this study, the proportion (34.4\%) of sexually active adolescents aged between $15-19$ years in a survey in Delta State $^{62}$ will be used $)^{[36]}$.

The sampling frame was the list of all senior secondary schools in the study area. Since the ratio of the number of secondary schools in Nnewi North LGA (45 schools) to those in Nnewi South LGA (38 schools) is approximately 1:1, 4 schools each were randomly selected for the study and the number and composition of students studied was determined using the multistage and proportionate sampling techniques and a minimum sample size of 380 as calculated.

In Nnewi North, there are 37 coeducation schools, 5 Girls only schools and 3 Boys only schools giving a total of 45 schools, thus 227, 31 and 18 students were studied in the coeducation, girls only and boys only schools respectively. While In Nnewi South, there are 35 coeducation schools, 2 Girls only schools and 1 Boys only schools giving a total of 38 schools, thus 96, 6 and 3 students were studied in the coeducation, girls only and boys only schools respectively.

Systematic sampling technique was the used to select the students that were studied in the chosen schools using the school list of senior secondary students in each school as the sampling frame.

The study instrument was a self-administered questionnaire, which wasa modified version of the Sexual Activity Survey by Diana Flannery and Lyndall Ellingson ${ }^{[37]}$. The questionnaire was designed to explore the sexual behaviours of senior secondary school students in regardsto socio-demographic factors, sexual debut, risk prevention measures, type of sexual practices, number of sexual partners and sexual orientation. It was pretested by 30 students from non-participating schools. A total of 450 questionnaires were administered and 439 (97.6\%) of these questionnaires were retrieved but only 394 copies (89.8\%) were completely answered.

The data was analyzed with Statistical Package for Social Sciences (SPSS) software package, version 20.0 and the results were presented in frequency tables.

Ethical approval for the study was obtained from the Nnamdi Azikiwe University Teaching Hospital Ethical Council. Permission was also obtained from the Post Primary School Service Commission and the State Ministry of Education, Nnewi Zone. Respondents were assured of confidentiality, privacy and anonymity of information provided and given the choice of not partaking in the study, if they so desired.

\section{Results}

Out of the 439 students interviewed in Nnewi North and South local government areas, the response of 394 was suitable for analysis, with 278 and 116 responses coming from each LGA respectively.Since there is no statistically significant difference between the results of both local governments $(\mathrm{P}=0.604)$, the results were combined. The age range of respondents was $12-24$ years with mean of $17 \pm$ 1.6years.

Table 1 shows the socio-demographic characteristics of the respondents. Both sexes were fairly represented with most respondents $(47.5 \%)$ in the first level of the senior class. $99.7 \%$ of the students were Christians of different denomination; $98.5 \%$ of them are of the Igbo tribe and $53.8 \%$ are from monogamous families. The parents of more than half $(52.5 \%)$ of the students had secondary education while only few (about 4\%) had no formal education.

Table 2 shows that, of the 394 respondents, 95 (24.1\%) admitted to previous sexual exposure of which 45 (47.4\%) were males while $50(52.6 \%)$ were females. Majority of the respondents who admitted to previous sex exposure were in the first class of the senior secondary school (53.7\%), from monogamous families $(50.5 \%)$ and have their schools located in Nnewi North LGA (68.4\%). However, there is no statistically significant relationship between previous sex exposure and gender, level of study, family setting and location of school, from the study.

From the study, minimum age at sexual debut was found to be 5 years and maximum age was 20years among the sexually active respondents.Table 3 shows that $23.2 \%$ of the respondents had their sexual debut below 10years of age, $31.6 \%$ between $10-13$ years, $36.8 \%$ between $14-17$ years and $8.4 \%$ between $18-20$ years of age. Mean age at sexual debut was $12 \pm 3.6$ years.Majority $(71.6 \%)$ of the sexually experienced respondents admitted that their first sexual exposure was unplanned. $22.1 \%$ of them were curious to have sex, $40 \%$ were deceived, $3.2 \%$ were drugged, $25.3 \%$ were forced, $4.2 \%$ were raped and $5.3 \%$ actually requested for it.

The method of sexual activity practiced by the sexually experienced respondents were vaginal (91.6\%), Anal (21.1\%) and oral (7.4\%).47.4\% of them had just one sexual partner. $45.2 \%$ had either 2 or 3 partners while $7.4 \%$ had more than 3 sexual partners.Among the sexually active respondents, $30.5 \%$ have homosexual inclination and $17.9 \%$ have forced someone to have sexual intercourse.Most of the respondents $(53.6 \%)$ first learnt about sex from media (Internet, TV, Newspaper, Magazines, romantic Novels, etc), while others learnt from parents $(11.4 \%)$, other siblings $(2.0 \%)$ and from friends (33\%).

The study showed that $74.7 \%$ of the respondents did not use condom during their first sexual exposure. Table 4 shows that $40 \%$ of them do not use any method of contraception, 26.3\% use condom, 9.5\% use birth control pills, 5.3\% use withdrawal method and $16.8 \%$ of them were not sure of the method they use.18.9\% of the sexually experienced respondents have been pregnant or gotten someone pregnant, majority $(83.3 \%)$ of which were terminated while the rest (16.7\%) had the delivery. $35.8 \%$ of respondents admitted to they or their partner having had one form of sexually transmitted infection or the other. 
Table 1. Socio-Demographic Characteristics $(N=394)$

\begin{tabular}{|c|c|c|}
\hline Variables & Frequency & Percentage \\
\hline \multicolumn{3}{|c|}{ Local Government Area } \\
\hline Nnewi North & 278 & 70.6 \\
\hline Nnewi South & 116 & 29.4 \\
\hline \multicolumn{3}{|l|}{ Sex } \\
\hline Male & 168 & 42.6 \\
\hline Female & 226 & 57.4 \\
\hline \multicolumn{3}{|l|}{ Class } \\
\hline SS1 & 187 & 47.5 \\
\hline $\mathrm{SS} 2$ & 129 & 32.7 \\
\hline SS3 & 78 & 19.8 \\
\hline \multicolumn{3}{|c|}{ Religion(Denomination) } \\
\hline Catholic & 204 & 51.8 \\
\hline Anglican & 125 & 31.7 \\
\hline Pentecostal & 64 & 16.2 \\
\hline Islam & - & - \\
\hline Traditional & 1 & 0.3 \\
\hline \multicolumn{3}{|l|}{ Tribe } \\
\hline Igbo & 388 & 98.5 \\
\hline Yoruba & 4 & 1.0 \\
\hline Hausa & 2 & 0.5 \\
\hline Others & - & - \\
\hline \multicolumn{3}{|l|}{ Family Setting } \\
\hline Monogamous & 212 & 53.8 \\
\hline Polygamous & 93 & 23.6 \\
\hline Single Parent & 89 & 22.6 \\
\hline \multicolumn{3}{|c|}{ Fathers' Education Level } \\
\hline None & 16 & 4.1 \\
\hline Primary & 84 & 21.3 \\
\hline Secondary & 207 & 52.5 \\
\hline Tertiary & 87 & 22.1 \\
\hline \multicolumn{3}{|c|}{ Mothers' Education Level } \\
\hline None & 19 & 4.8 \\
\hline Primary & 58 & 14.7 \\
\hline Secondary & 218 & 55.3 \\
\hline Tertiary & 99 & 25.1 \\
\hline
\end{tabular}

Table 2. Factors associated with Sexual Behaviour

\begin{tabular}{|c|c|c|c|}
\hline \multirow{2}{*}{ Factors } & \multicolumn{2}{|c|}{ Previous sex } & \multirow{2}{*}{ P-values } \\
\hline & YES & NO & \\
\hline \multicolumn{4}{|l|}{ Sex } \\
\hline Male & $\begin{array}{l}45 \\
(26.8 \%)\end{array}$ & $\begin{array}{l}123 \\
(73.2 \%)\end{array}$ & \multirow{2}{*}{0.548} \\
\hline Female & $\begin{array}{l}50 \\
(22.1 \%)\end{array}$ & $\begin{array}{l}176 \\
(77.9 \%)\end{array}$ & \\
\hline \multicolumn{4}{|l|}{ Class } \\
\hline SS1 & $\begin{array}{l}51 \\
(27.3 \%)\end{array}$ & $\begin{array}{l}136 \\
(72.7 \%)\end{array}$ & \multirow{3}{*}{0.213} \\
\hline $\mathrm{SS} 2$ & $\begin{array}{l}25 \\
(19.4 \%)\end{array}$ & $\begin{array}{l}104 \\
(80.6 \%)\end{array}$ & \\
\hline SS3 & $\begin{array}{l}19 \\
(24.4 \%)\end{array}$ & $\begin{array}{l}59 \\
(75.6 \%)\end{array}$ & \\
\hline \multicolumn{4}{|l|}{ Family Setting } \\
\hline Monogamous & $\begin{array}{l}48 \\
(22.6 \%)\end{array}$ & $\begin{array}{l}164 \\
(77.4 \%)\end{array}$ & \multirow{3}{*}{0.648} \\
\hline Polygamous & $\begin{array}{l}23 \\
(24.7 \%)\end{array}$ & $\begin{array}{l}70 \\
(75.3 \%)\end{array}$ & \\
\hline Single Parent & $\begin{array}{l}24 \\
(27.0 \%)\end{array}$ & $\begin{array}{l}65 \\
(73.0 \%)\end{array}$ & \\
\hline \multicolumn{4}{|l|}{ LGA } \\
\hline Nnewi North & $\begin{array}{l}65 \\
(23.4 \%)\end{array}$ & $\begin{array}{l}213 \\
(76.6 \%)\end{array}$ & \multirow{2}{*}{0.604} \\
\hline Nnewi South & $\begin{array}{l}30 \\
(25.9 \%)\end{array}$ & $\begin{array}{l}86 \\
(74.1 \%) \\
\end{array}$ & \\
\hline
\end{tabular}

Statistically significant if $\mathrm{p}>0.05$
Table 3. Pattern of Sexually Active Respondents $(N=95)$

\begin{tabular}{lll}
\hline Variables & Frequency & Percentage \\
\hline Age at Sexual Debut & & \\
$<10$ years & 22 & 23.2 \\
10 -13 years & 30 & 31.6 \\
14 -17 years & 35 & 36.8 \\
18-20 years & 8 & 8.4 \\
First Sexual Intercourse & & \\
Planned & 27 & 28.4 \\
Unplanned & 68 & 71.6 \\
Method of Sex & & \\
Vaginal & 87 & 91.6 \\
Oral & 7 & 7.4 \\
Anal & 20 & 21.1 \\
Number of sexual Partner & & \\
1 & 45 & 47.4 \\
2 & 29 & 30.5 \\
3 & 14 & 14.7 \\
$>3$ & 7 & 7.4 \\
Homosexual Experience & 29 & 30.5 \\
\hline
\end{tabular}

Table 4. Respondents' Contraceptive Use for Prevention of Pregnancy and STIS $(N=95)$

\begin{tabular}{lll}
\hline Variables & Frequency & Percentage \\
\hline Method of Pregnancy Prevention & & \\
None & 38 & 40.0 \\
Condom & 25 & 26.3 \\
Birth Control Pills & 9 & 9.5 \\
Injectables & - & - \\
Withdrawal & 5 & 5.3 \\
Unknown & 16 & 16.8 \\
Number of Pregnancy & & \\
None & 77 & 81.1 \\
1time & 10 & 10.5 \\
2 or More times & 8 & 8.4 \\
Pregnancy Outcome & & \\
Delivery & 3 & $16.7(\mathrm{n}=18)$ \\
Abortion & 15 & $83.3(\mathrm{n}=18)$ \\
Previous STI & 34 & 35.8 \\
\hline
\end{tabular}

\section{Discussion}

Adolescent reproductive health issues have been particularly of interest in the last two decades because of widespread HIV/AIDS. Several researchers have made efforts to find measures to curb the unacceptable prevalence of HIV/AIDS and other STIs among the youths.Data from some states in the country indicate that adolescents engage in unhealthy sexual behaviours characterized by early age at sexual initiation, unsafe sex and multiple sexual partners ${ }^{[38-}$ 48]

The socio-demographic characteristics of students studied were comparable to previous findings in Nigeria ${ }^{[49-51,52-54]}$ but unlike the previous studies, most respondents in this study were from monogamous settings and more than half of their parents had completed secondary education ${ }^{[61]}$.From this study, there was no statistically significant relationship between the socio-demographic characteristics of the respondents and their sexual exposure unlike the study done by Morhason-Bello et al at Ibadan in which a higher proportion of respondents with previous sexual exposure were males $(p=0.00043)^{[61]}$. 
From this study, $24.1 \%$ of the respondents have had previous sexual experience; $26.4 \%$ of all males and $22.1 \%$ of all female respondents, indicating that more of the male respondents have had previous sexual exposure than the females. This is in agreement with some studies done by the CDC in $2011^{[25,26]}$, Delva et al among the Balkans ${ }^{[55]}$, studies done in Sweden ${ }^{[56]}$ and in India ${ }^{[57]}$, which showed that sexual activity tends to be relatively higher among boys than girls. However, the reverse is the case among the Ghanaian adolescents as reported by Delva et al ${ }^{[58]}$ and in the study done in Nigeria, which showed that sexual activity tends to be higher among females than males in Nigeria ${ }^{[27]}$. Okpani et al reported $78.8 \%$ sexual exposure among the adolescents in Port Harcourt. He suggested that the increased sexual activity among in-school adolescents in Port Harcourt might be due to rapid urbanization ofthe city as Nigeria's crude oil operations expand; coupled with the poor socioeconomic background of the indigenous adolescent ${ }^{[60]}$.

From this study, mean age at sexual debut was $12 \pm 3.6$ years. The in-school adolescents who are sexually active had initial sexual exposure at about the same age in Nnewi North and South LGAs like their peers in Port Harcourt and Ibadan ${ }^{[60,61]}$. However, this mean age at sexual debut is low compare to some others from previous studies ${ }^{[62,51,63,54]}$. This study revealed further that $23.2 \%, 31.6 \%, 36.8 \%$ and $8.4 \%$ had their sexual debut before $10^{\text {th }}$ year birthday, between $10-13$ years, 14-17 years and 18-20 years respectively. These percentages showed that most of the sexually active respondents had their sexual debut before they were 17 years old. This is greater than previous studies in several parts of the country ${ }^{[27,39,64]}$. Sexual debut at an earlier age has been associated with increased risk ofcervical cancer ${ }^{[65]}$; viral infections (HIV, HPV etc) ${ }^{[66]}$; bacterial infection (gonorrhoea, Chlamydia trachomatis) ${ }^{[67,68]}$. Studies have also shown that adolescent with earlier sexual debut tend to have multiple partners per unit time ${ }^{[69]}$.

More worrisome is the context in which this sexual debut occurs. Most of the sexually experienced respondents in this study admitted that their first exposure was unplanned (71.6\%). In this study, it was established that $3.2 \%$ of them were drugged, $4.2 \%$ were raped, $25.3 \%$ were forced and $40 \%$ were deceived into having sex. $22.1 \%$ of them attributed their first sexual encounter to curiosity about sex and 5.3\% said they actually requested sex. On the whole only about $27.3 \%$ of sexual debut by the adolescents seem to have been by mutual consent. These findings agree with the earlier report from the Nigerian studies in Ibadan ${ }^{[61]}$ and $\mathrm{Abala}^{[48]}$.

The method of sexual activity practiced by the respondents was mostly vaginal (91.6\%). Atleast one in five of the respondents in this study engaged in anal sex and $7.4 \%$ in oro-genital sex. These two methods have been associated with increased risk of HIV and other STIs transmission compared to vaginal sex ${ }^{[70,71]}$. This may be a reflection that homosexuality is now gaining ground in our society contrary to the earlier belief of only being popular in western countries. In fact, $30.5 \%$ of these students reported having had homosexual experience.
Most respondents, like their peers in other parts of the country ${ }^{[61,72]}$, first learnt about sexual issues from the media $(53.6 \%)$ and their school-mates/ friends (33\%), sources often not properly informed about adolescent reproductive issues. A report however has indicated increased parents' participation in sex education now more than in the past ${ }^{[73]}$. This is a welcome development because they will be in a better position to guide their children against unsafe sexual practices.

Unfortunately the level of sexual activity has not been matched by a commensurate level of contraception practice as $40 \%$ ofrespondents do not use any form of contraception and only $26.3 \%$ use condom. This is comparable to studies in other parts of the country, some of which reported even lower contraceptive usage ${ }^{[60,48,74,63,54]}$.

Unwanted pregnancy is also a notable outcome of adolescent sexual activity in Nigeria. The rate in this study was $18.9 \%$. Most studies have documented an 'ever pregnant' rate between $18.4 \%$ and $39.1 \%{ }^{[39,42-44]}$. These pregnancies have in most cases been terminated. Documented rate of abortion among 'ever pregnant' adolescent girls in the Niger Delta Region of Nigeria ranged between $33.0 \%$ and $88.6 \%{ }^{[39,42,60,48]}$, the rate of abortion in this study was $83.3 \%$.In Nigeria, the law restricts abortion, thus most of these abortions are done illegally and by unskilled personnel under septic conditions ${ }^{[75]}$. About 610,000 induced abortions are carried out in Nigeria annually ${ }^{[33]}$ and it is estimated that 20,000 out of the 50,000 maternal deaths are related to abortion and its complications ${ }^{[76]}$.Pregnant adolescent girls who do not succeed in procuring an abortion go on to have a delivery and are thus exposed to the risks associated with teenage pregnancy, labour and delivery.

From this study, $35.8 \%$ of the sexually active adolescents had experienced STI. This is in keeping with the report of Brabin et al which showed that $42.1 \%$ of sexually active adolescents had experienced either abortion or $\mathrm{STI}^{[64]}$. It is known that a pre-existing STI increases susceptibility to acquiring HIV infection. STIs if not properly treated could lead to infertility in future. This raises the question of the quality of care obtained by the respondents who sought treatment for the infection outside the health facilities.

\section{Conclusion}

It can be concluded from this study that at least one out of every five in-school adolescents in Nnewi North and South LGAs is sexually active. Most engage in unsafe sexual practices and are thus prone unwanted pregnancy and its complications and contracting STIs including HIV/AIDS. Most of them do not have access to any form of formal sex education and majority of them terminate unwanted pregnancies which in the face of the restrictive abortion laws of Nigeria, are done in sub-standardcentres by unskilled personnel thus posing a problem to their reproductive health.

In lieu of the findings from the above study, the following recommendations have been made viz: Increased political 
will and government commitment to adolescent reproductive health issues, incorporation of school-based interventions relating to sexuality education, family life and STIs including HIV/AIDS education into the school system, capacity building for adolescent reproductive health personnel and support for more research on adolescent reproductive health issues.Abstinence and chastity should be preached and upheld in the society and youth-friendly fora where morality is upheld should be promoted in schools.

\section{References}

[1] Singh. SA, Wulf D. Early Child bearing in Nigeria: A Continuing Challenge. Research in Brief.

[2] Moronkola OA, Idris OM. Sexual health knowledge, determinants of sexual behaviour and use of contraceptives among female secondary school students in Ibadan, Nigeria. Niger School Health. 2000; 12: 27-35.

[3] Esiet A. Building support for adolescent health education and services in Nigeria: reflections from the experience of Action Health Incorporated (AHI). 2003. New York, NY.

[4] Murray N, Winfrey W, Chatterji M, Moreland S, Dougherty L, Okonofua F. Factors Related to Induced Abortion among Young Women in Edo State, Nigeria. Studies in Family Planning. 2006; 37, 4 (12):251-268.

[5] Arowojolu AO, Ilesanmi AO, Roberts OA, Okunola MA. Sexuality, contraceptive choice and AIDS awareness among Nigerian undergraduates. African Journal of Reproductive Health. 2002; 6 (2): 60-70.

[6] Gebhard P. Human sexual behaviour. Encyclopedia Britannica www.britannica.com/EBchecked/topic/537102/human-sexualbehaviour. Accessed on 3:11:2014

[7] Crossette B. Reproductive Health and the Millennium Development Goals: The Missing Link. Stud FamPlann , 2005; 36(1):71-79.

[8] Marston C, King E. Factors that shape young people's sexual behaviour: a systematic review. Lancet 2006, 368(9547):1581-1586.

[9] Tang J, Gao XH, Yu YZ, Ahmed NI, Zhu HP, Wang JJ, Du YK Sexual Knowledge, attitudes and behaviors among unmarried migrant female workers in China: a comparative analysis. BMC Publ Health 2011, 11:917.

[10] Olukoya A A, Ferguson DJ. Adolescent sexual and Reproductive Health and development. Archives of Ibadan Medicine, 2002; 3(1): 22-27.

[11] Olukoya AA and Ferguson DJ. Background Information on puberty. Un published paper. WHO Geneva, 2001.

[12] Chichetti D, Beeghly M. The self in transition; Infancy to child hood. Chicafo; University of Chicago press, 1990; 61- 97.

[13] World Health Organisation. Regional office for Africa. Adolescent health: A strategy for the African Region. AFR/R151/10 Rev. 1 Brazzaville 2001.

[14] Okonofua FE. Adolescent Reproductive Health in Africa: The future challenges. African Journal of Reproductive Health, 2000; 4(1): 7-9.
[15] World Health Organization. Broadening the Horizon: Balancing protection and risk for adolescents. WHO/FCH/CAH/01.20. Geneva, 2001.

[16] Gottlieb SM, Melchizedex TL. Abortion and unmet need for contraception in Tanzania - The role of male partners in Teenage induced Abortion in Dar Es Salaam. Africa Journal of Reproductive Health, 1998; 2(2): 109-121.

[17] Feyisetan B, Pebley AR. Premature sexuality in urban Nigeria. Stud. Family planning 1989; 20:343-354.

[18] Barbin L, Kemp J, Obunge O. Reproductive tract infections and abortions among adolescent girls in rural Nigeria. Lancet, $1995 ; 345: 300-304$.

[19] Sunmola A M, Dipeolu M, Babalola S, Out AD. Reproductive, sexual and contraceptive behaviour of Adolescents in Niger stage, Nigeria. Afr J Reprod Health, 2002; 6(3): 82-92.

[20] Okpani A O, Okpani JU. Sexual activity and contraceptive use among female adolescents: A report from Port Harcourt, Nigeria. Africa Journal of Reproductive Health. 2000; 4(1):4147.

[21] Briggs ND. Adolescent sexuality and its problems in an African society. Nigeria FIGO concept paper; Adolescent Gynaecology, 1991; 235-239.

[22] Adedoyin M, Adegoke A A. Teenage prostitution - Child abuse: a survey of Ilorin station. African Journal Med. 86, 1995; $24: 27-31$.

[23] UNAIDS (2006) Report on the global AIDS epidemic assessed from www.unaids.org on 10/08/2011.

[24] Federal Ministry of Health (FMOH). National HIV/AIDS and Reproductive Health Survey. 2003. Abuja, Nigeria.

[25] Centers for Disease Control and Prevention (CDC). 19912011 High School Youth Risk Behavior Survey Data. Retrieved on July 2, 2012, from http://apps.nccd.cdc.gov/youthonline

[26] Centers for Disease Control and Prevention (CDC). (2012). Youth Risk Behavior Surveillance-United States, 2011.Morbidity and Mortality Weekly Report (MMWR), 61(4), 1-268. Retrieved on July 2, 2012, from www.cdc.gov/mmwr/pdf/ss/ss6104.pdf

[27] National Population Commission (NPC) [Nigeria] and ORC Macro. Nigeria Demographic and Health Survey 2009. 2008. Calverton, Maryland.

[28] Bankole A et al., Risk and Protection: Youth and HIV/AIDS in Sub-Saharan Africa. 2004. New York.

[29] Sedgh G, Bankole A, Okonofua F, Imarhiagbe C, Hussain R, Wulf D. Meeting Young Women's Sexual and Reproductive Health Needs in Nigeria. 2009. New York.

[30] Iwuagwu SC, Ajuwon AJ, Olasheha IO. Sexual behaviour and negotiation of male condoms by female students of the University of Ibadan. Journal of Obstetrics and Gynaecology. 2000; 20 (5): 507-513.

[31] Adinma DE, Joseph IBA, Nkemakolam OE, Chima I, Akinsewa A, Ejike O. Awareness and use of contraception by women seeking termination of pregnancy in south eastern Nigeria. Asian Pacific Journal of Tropical Disease. 2011; 7175 . 
[32] Federal Ministry of Health. National HIV/AIDS Reproductive Health Survey. 2007. Abuja, Nigeria.

[33] Henshaw SK, Singh S, Oye-Adeniran B, Adewole IF, Iwere N, Cuca Yvete P. The incidence of induced abortion in Nigeria. Int Fam Plann Perspect. , 1998; 24: 156-64.

[34] 34. UNFPA.UNFPA assisted $5^{\text {th }}$ Country Programme Baseline survey 2004: Delta state report.

[35] Anambra state post primary school, www.ansppsschqtrs.com/schools.php

[36] Araoye MO. Research methodology with statistics for health and social sciences. First edition. Ilorin: Nathadex publishers, 2003: 117-120.

[37] Flannery D, Ellington L. Sexual Risk Behaviours among First Year College Students. Californian Journal of Health Promotion, 2003; 1(3): 93-104.

[38] National Population Commission (Nigeria) and ORC Macro. Nigeria Demographic and Health Survey 2003. Calverton, Maryland, USA. National Population Commission and ORC Macro, 2004.

[39] Anochie I.C, Ikpeme E.E. Prevalence of sexual activity and outcome among female secondary school students in PortHarcourt, Nigeria. Afr J Reprod Health, 2001; 5(2): 63-67.

[40] Ogbuagu SC, Charles J.O. Survey of sexual networking in Calabar. Hlth Trans Rev, 1993; 3 (suppl): 105-120.

[41] Evelyn U.I. and Osafu O. Sexual behaviour and perception of AIDS among adolescent girls in Benin-city, Nigeria. Afr J Reprod Health 1999; 3:39-44.

[42] Kemp JR. A study of sexual behaviour and RH of adolescent girls in South East Nigeria. PhD thesis 2000. University of Liverpool.

[43] Okpani AO, Okpani JU. Sexual activity and contraceptive use among female adolescents- A report from Port Harcourt, Nigeria. Afri J. Reprod Health, 4 (1), 40-47.

[44] Etuk SJ, Ihejieamaizu EC, Etuk IS. Female adolescent sexual behaviour in Calabar, Nigeria. Niger Postgrad Med J. , 2004; 11(4): 269-73.

[45] UNFPA.UNFPA assisted $5^{\text {th }}$ Country Programme Baseline survey 2004: Delta state report.

[46] Oboro VO, Tabowei TO. AIDS prevention programmes and sexual behaviour among secondary school adolescents in Delta state, Nigeria. Trop J. Obst and Gynaecol , 2003; 20(1).

[47] Singh S, Audan S, and Wulf D. Early child bearing in Nigeria: a continuing challenge, Research in Brief, New York: The Alan Guttmacher Institute, 2004; 2.

[48] Chimaraoke OI. Tasting the forbidden fruit: The social context of debut sexual encounters among young persons in a rural Nigerian community. Afri J Reprod Health, 2001; 5(2): 22-29.

[49] Envuladu EA, Agbo HA, Ohize VA, Zoakah AI. Journal of Medical Research, 2013; 2(2): 0117-0122.

[50] Morhason-Bello IO, Oladokun A, Enakpene CA, Fabamwo AO, Obisesan KA, Ojengbede OA. Sexual behaviour of inschool adolescents in Ibadan, South west Nigeria. Afr J Reprod Health, 2008; 12(2):89-97.
[51] Ajuwon AJ, Olaleye A, Faromoju B and Oladapo Ladipo O. Sexual behaviour and experience of sexual coercion among secondary school students in three states in North Eastern Nigeria. BMC Public Health, 2006; 6:310.

[52] Nwokocha ARC, Bob-Okon I, Ibe BC. Social Factors Predisposing Nigerian Adolescents in Enugu to STI. World J Life Sci. and Medical Research 2012; 2(5):186.

[53] Nwankwo BO, Nwoke EA. Risky sexual behaviours among adolescents in Owerri Municipal: predictors of unmet family health needs. Afr J Reprod Health. 2009 Mar; 13(1):135-45.

[54] Nwagwu W, Okoye I, Isiugo-Abanihe I. HIV/AIDS information source use and sexual behaviour of adolescents in Ekwusigo Local Government Area of Anambra State, Nigeria. Journal of AIDS and HIV Research 2011; Vol. 3(8), pp. 138150 .

[55] Delva W, Wuillaume F, Vansteelandt S, Claeys P, Verstraelen $\mathrm{H}$, Temmerman M. Sexual behavior and contraceptive use among youths in the Balkans. Eur J Contracept Reprod Health Care. 2007 Dec; 12(4):309-16.

[56] Haggstrom-Nordin E, Borneskog C, Eriksson M, Tyden T. Sexual behaviour and contraceptive use among Swedish high school students in two cities: Comparisons between genders, study programmes, and over time. The European Journal of Contraception and Reproductive Health Care, February 2011; $16: 36-46$

[57] Shashikumar R, Das RC, Prabhu HRA, Srivastava K, Bhat PS, Prakash J, Seema P. A cross-sectional study of factors associated with adolescent sexual activity. Indian J Psychiatry. 2012 Apr-Jun; 54(2): 138-143.

[58] Glover EK, Bannerman A, Pence BW, Jones H, Miller R, Weiss E, Nerquaye-Tetteh J. Sexual Health Experiences of Adolescents in Three Ghanaian Towns. International Family Planning Perspectives, 2003; 29(1).

[59] Okpani AO, Okpani JU. Sexual activity and contraceptive use among female adolescents- A report from Port Harcourt, Nigeria. Afri J. Reprod Health, 4 (1), 40-47.

[60] Morhason-Bello IO, Oladokun A, Enakpene CA, Fabamwo AO, Obisesan KA, Ojengbede OA. Sexual behaviour of inschool adolescents in Ibadan, South west Nigeria. Afr J Reprod Health, 2008; 12(2):89-97.

[61] Etuk SJ, Ihejieamaizu EC, Etuk IS. Female adolescent sexual behaviour in Calabar, Nigeria. Niger Postgrad Med J. , 2004; 11(4): 269-73.

[62] Bamidele JO, Abodunrin OL, Adebimpe WO. Sexual behaviour and risk of HIV/AIDS among adolescents in public secondary schools in Osogbo, Osun State, Nigeria. Int J Adolesc Med Health, 2009; 21(3):387-94.

[63] Brabin L, Kemp J, Obunge OK, Ikimalo J, Briggs ND, Odu NN, Hart CA. Reproductive tract infections and abortions among adolescent girls in rural Nigeria. Lancet, 1995; 345: 300-304.

[64] Edehiri A A. Cervical Intraepithelial Neoplasia: The role of age at first coitus in its etiology. J Reprod Med 1990; 35:256259.

[65] Kjaer SK, Engholon G, Teisen C. Risk factors for cervical human papilloma virus and herpes simplex virus infection in Greenland and Denmark: a population based study. In: Am. J. Epidemiol. (1990)131:669-82. 
[66] Phillips RS, Hanff PA, Werheimer A, Aronson MD. Gonorrrhoea in Women seen for routine gynaecological care: Criteria for testing. Am. J. Med (1998) 85:177-82

[67] Shafer MA, Beck A, Blain B. Chlamydia trachomatis: Important relationships to race, Contraception, Lower genital infection and Papanicolaou smear. J .Paed (1984) 104:141-6.

[68] CDC, Premarital sexual experience among Adolescent women, United States, 1970-1988. MMWR 1990; 39(51,52):929-32.

[69] FMOH. HIV/Syphilis sentinel survey results 2003, Abuja Nigeria: Ministry of Health, 2004.

[70] Okonofua FE, Shittu SO, Oronsaye F, Ogunshakin D, Ogbomwan S, Zayyan M. Attitudes and practices of private medical providers towards family planning and abortion services in Nigeria. Acta Obstet Gynecol Scand, 2005; 84: 270-280.

[71] Nwankwo BO, Nwoke EA. Risky sexual behaviours among adolescents in Owerri Municipal: predictors of unmet family health needs. Afr J Reprod Health. 2009 Mar; 13(1):135-45.
[72] Ekott MI. Attitude of parents to their adolescent children's sexuality: A study of health care workers in Calabar. Tropical Journal of Obstetrics and Gynaecology 2003; 20(Suppl 1):S22.

[73] Orji EO, Esimai OA. Sexual behaviour and contraceptive use among secondary school students in Ilesha south west Nigeria. J Obstet Gynaecol., 2005; 25(3):269-72.

[74] Okonofua FE, Shittu SO, Oronsaye F, Ogunshakin D, Ogbomwan S, Zayyan M. Attitudes and practices of private medical providers towards family planning and abortion services in Nigeria. Acta Obstet Gynecol Scand, 2005; 84: 270-280.

[75] Okonofua FE, Ilumoka A. Prevention of morbidity and mortality from unsafe abortion in Nigeria: Critical issues in RH, The Robert Program, New York Population Council, 1992. 